\title{
Modulation of MMP-2 and MMP-9 secretion by cytokines, inducers and inhibitors in human glioblastoma T-98G cells
}

\author{
M. WAHEED ROOMI, TATIANA KALINOVSKY, MATTHIAS RATH and ALEKSANDRA NIEDZWIECKI
}

Dr. Rath Research Institute, Santa Clara, CA 95050, USA

Received November 8, 2016; Accepted December 30, 2016

DOI: $10.3892 /$ or.2017.5391

\begin{abstract}
Brain tumors are highly aggressive, characterized by the secretion of high levels of matrix metalloproteinase (MMP)-2 and MMP-9 that degrade the extracellular matrix and basement membrane, allowing cancer cells to spread to distal organs. Various cytokines, mitogens, growth factors, inducers and inhibitors control MMP activity. We investigated the roles of these in the regulation of MMP-2 and MMP-9 in human glioblastoma T-98G cells. Human T-98G cells were grown in DME supplemented with $15 \%$ fetal bovine serum and antibiotics in 24-well tissue culture plates. At near confluence, cells were washed with phosphate-buffered saline and incubated in serum-free media with: phorbol 12-myristate 13 -acetate (PMA) at 10, 25, 50 and $100 \mathrm{ng} / \mathrm{ml}$; tumor necrosis factor (TNF)- $\alpha$ and interleukin (IL)- $1 \beta$ at $0.1,1,10$ and $25 \mathrm{ng} / \mathrm{ml}$; lipopolysaccharide (LPS) at 10, 25, 50 and $100 \mu \mathrm{g} / \mathrm{ml}$; epigallocatechin gallate (EGCG) and doxycycline (Dox) at 10, 25, 50 and $100 \mu \mathrm{M}$ without and with PMA; a nutrient mixture (NM) containing lysine, proline, ascorbic acid and green tea extract without and with PMA at 10, 50, 100, 500 and $1,000 \mu \mathrm{g} / \mathrm{ml}$; actinomycin D and cyclohexamide at 2 and $4 \mu \mathrm{M}$; retinoic acid and dexamethasone at $50 \mu \mathrm{M}$. After $24 \mathrm{~h}$ the media were removed and analyzed for MMP-2 and MMP-9 by zymography and densitometry. Glioblastoma T-98G cells expressed only one band corresponding to MMP-2. PMA treatment showed increased MMP-2 and MMP-9 secretions up to $25 \mathrm{ng} /$ $\mathrm{ml}$ and decreased levels of secretions at 50 and $100 \mathrm{ng} / \mathrm{ml}$, with no significant overall effect. TNF- $\alpha$ induced an up and down effect on MMP-2 and a slight induction of MMP-9. IL-1 $\beta$ demonstrated a slight dose-dependent increase in T-98G secretion of MMP-2, but no induction of MMP-9. LPS showed dose-dependent decreased inactive MMP-2 secretion, increased active MMP-2 secretion and no effect on MMP-9. EGCG, Dox and NM, without and with PMA, downregulated
\end{abstract}

Correspondence to: Dr Aleksandra Niedzwiecki, Dr. Rath Research Institute, 1260 Memorex Drive, Santa Clara, CA 95050, USA

E-mail: author@drrath.com

Key words: matrix metalloproteinases, glioblastoma T-98G, cytokines, inducers, inhibitors the expression of MMP-2 and MMP-9 in a dose-dependent manner. Actinomycin D, cyclohexamide, retinoic acid and dexamethasone also had inhibitory effects on MMP-2. Our results showed that cytokines, mitogens and inhibitors modulated T-98G cell MMP-2 and MMP-9 expression, suggesting the clinical use of MMP inhibitors, particularly such potent and non-toxic ones as the nutrient mixture and its component EGCG in the management of glioblastoma cancers.

\section{Introduction}

The American Cancer Society estimated 23,670 new cases and 16,050 deaths from brain and nervous system tumors in adults and children in 2015 (1). The most common causes of cancer-related deaths in adolescents and young adults aged 15-39 are malignant brain tumors (2). Gliomas, tumors arising from the supportive tissue of the brain, represent $27 \%$ of all brain tumors and $80 \%$ of all malignant tumors (2). Glioblastomas, which represent $15.1 \%$ of all primary brain tumors and $55.1 \%$ of all gliomas, constitute the highest number of cases of all malignant tumors, with an estimated 12,120 new cases predicted in 2016 (2).

Brain tumors are prone to recur locally or invade other regions of the central nervous system (CNS). Tumor cell invasion is dependent upon degradation of the extracellular matrix (ECM), which, when intact, acts as a barrier to block cancer cell invasion (3-5). Numerous clinical and experimental studies have demonstrated that elevated levels of matrix metalloproteinases (MMPs) are associated with the progression of brain tumors. Elevated levels of several MMPs, such as MMP-1, MMP-2, MMP-7, MMP-9, MMP-11, MMP-12, MMP-14, MMP-15, MMP-19, MMP-24 and MMP-25 have been reported in malignant glioma samples from patients, suggesting that malignant progression is correlated to MMP expression (6). Jäälinojä et al found that mean survival in patients with MMP-2-negative tumors was 36 months in contrast to 7-14 months in those patients with MMP-2-positive tumors (7). Smith et al reported that immunohistochemical examination of urine, cerebrospinal fluid and tissue specimens from patients with brain tumors, revealed a significant correlation between brain tumor presence and elevated MMP-2 and MMP-9 levels and that resection of tumors correlated with decreased levels of MMPs (8).

MMP activity is regulated by and dependent upon environmental influences from surrounding stroma cells, ECM 
proteins, systemic hormones and other factors. Inflammation has been reported to drive cancer progression (9-11). Inflammatory cytokines such as interleukin (IL)-1 $\beta$ and tumor necrosis (TNF)- $\alpha$ play significant roles in inflammation driven tumor growth and progression $(12,13)$. These cytokines were found to be upregulated following radiation therapy in glioblastoma patients $(14,15)$. Ilyin et al noted that IL-1 $\beta$ drives neuroinflammation by upregulating expression of other pro-inflammatory cytokines (16). Ryuto et al reported the induction of vascular endothelial growth factor (VEGF) expression by TNF- $\alpha$ in gliomas, which leads to the increased angiogenesis observed in these tumors (17).

In the present study, we investigated the effects of select cytokines, inducers and inhibitors affecting cancer cell metabolism on the regulation of MMP-2 and MMP-9 activities in the glioblastoma T-98G cell line.

\section{Materials and methods}

Materials. Human glioblastoma T-98G cells were obtained from the American Type Culture Collection (ATCC; Rockville, MD, USA). Antibiotics, penicillin and fetal bovine serum (FBS) were obtained from Gibco-BRL (Long Island, NY, USA). Twenty-four well tissue culture plates were obtained from Costar (Cambridge, MA, USA). Gelatinase zymography was performed on $10 \%$ Novex pre-cast SDS polyacrylamide gel (Invitrogen Inc., Carlsbad, CA, USA) with $0.1 \%$ gelatin in non-reducing conditions. Interleukin-1 $\beta$ (IL-1 $\beta$ ), tumor necrosis factor- $\alpha$ (TNF- $\alpha$ ), phorbol 12-myristate 13-acetate (PMA), lipopolysaccharide (LPS), doxycycline, epigallocatechin gallate (EGCG), actinomycin D, cyclohexamide, retinoic acid and dexamethasone were purchased from Sigma (St. Louis, MO, USA). The nutrient mixture (NM), prepared by VitaTech (Hayward, CA, USA), was composed of the following ingredients in the relative amounts indicated: vitamin $\mathrm{C}$ (as ascorbic acid and as $\mathrm{Mg}, \mathrm{Ca}$ and palmitate ascorbate) $700 \mathrm{mg}$; L-lysine 1,000 mg; L-proline $750 \mathrm{mg}$;

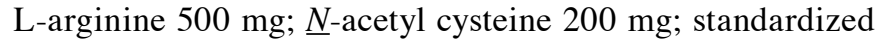
green tea extract ( $80 \%$ polyphenol) $1,000 \mathrm{mg}$; selenium $30 \mu \mathrm{g}$; copper $2 \mathrm{mg}$; manganese $1 \mathrm{mg}$. All other reagents used were of high quality and were obtained from Sigma, unless otherwise indicated.

Cell cultures. Glioblastoma cells were grown in DME, supplemented with $15 \% \mathrm{FBS}, 100 \mathrm{U} / \mathrm{ml}$ penicillin and $100 \mu \mathrm{g} / \mathrm{ml}$ streptomycin in 24 -well tissue culture plates. The cells were plated at a density of $1 \times 10^{5}$ cells $/ \mathrm{ml}$ and grown to confluency in a humidified atmosphere at $5 \% \mathrm{CO}_{2}$ at $37^{\circ} \mathrm{C}$. Serum-supplemented media were removed and the cell monolayer was washed once with phosphate-buffered saline (PBS) and with the recommended serum-free media. The cells were then incubated in $0.5 \mathrm{ml}$ of serum-free medium with various cytokines, mitogens, inducers and inhibitors in triplicates, as indicated: PMA $(10,25,50$ and $100 \mathrm{ng} / \mathrm{ml}) ;$ TNF- $\alpha$ and IL- $1 \beta$ $(0.1,1,10$ and $25 \mathrm{ng} / \mathrm{ml})$; LPS $(10,25,50$ and $100 \mu \mathrm{g} / \mathrm{ml}) ;$ EGCG $(10,25,50$ and $100 \mu \mathrm{M})$ without and with PMA $100 \mathrm{ng} / \mathrm{ml}$; doxycycline $(10,25,50$ and $100 \mu \mathrm{M})$ without and with PMA $100 \mathrm{ng} / \mathrm{ml}$; NM $(10,50,100,500$ and $1,000 \mu \mathrm{g} / \mathrm{ml})$ without and with PMA $100 \mathrm{ng} / \mathrm{ml}$, retinoic acid $(50 \mu \mathrm{M})$; dexamethasone $(50 \mu \mathrm{M})$; actinomycin D and cyclohexamide (2 and $4 \mu \mathrm{g} / \mathrm{ml})$.
The plates were then returned to the incubator. The conditioned medium from each treatment was separately collected, pooled and centrifuged at $4^{\circ} \mathrm{C}$ for $10 \mathrm{~min}$ at 3,000 rpm to remove cells and cell debris. The clear supernatant was collected and used for gelatinase zymography, as described below.

Gelatinase zymography. Gelatinase zymography was utilized due to its high sensitivity to gelatinolytic enzymatic activity and ability to detect both pro and active forms of MMP-2 and MMP-9. Upon renaturation of the enzyme, the gelatinases digest the gelatin in the gel and reveal clear bands against an intensely stained background. Gelatinase zymography was performed using $10 \%$ Novex pre-cast SDS polyacrylamide gel in the presence of $0.1 \%$ gelatin under non-reducing conditions. Culture media $(20 \mu \mathrm{l})$ were mixed with sample buffer and loaded for SDS-PAGE with Tris-glycine SDS buffer, as suggested by the manufacturer (Novex). Samples were not boiled before electrophoresis. Following electrophoresis, the gels were washed twice in $2.5 \%$ Triton X-100 for $30 \mathrm{~min}$ at room temperature to remove SDS. The gels were then incubated at $37^{\circ} \mathrm{C}$ overnight in substrate buffer containing $50 \mathrm{mM}$ Tris- $\mathrm{HCl}$ and $10 \mathrm{mM} \mathrm{CaCl}_{2}$ at $\mathrm{pH} 8.0$ and stained with $0.5 \%$ Coomassie Blue R250 in 50\% methanol and 10\% glacial acetic acid for $30 \mathrm{~min}$ and destained. Protein standards were concurrently run and approximate molecular weights were determined by plotting the relative mobilities of known proteins. Gelatinase zymograms were scanned using CanoScan 9950F Canon scanner at $300 \mathrm{dpi}$. The intensity of the bands was evaluated using the pixel-based densitometer program Un-Scan-It, version 5.1, 32-bit, by Silk Scientific Corporation (Orem, UT, USA), at a resolution of 1 Scanner Unit (1/100 of an inch for an image that was scanned at $100 \mathrm{dpi}$ ).

Statistical analysis. Microsoft Excel 2010 linear trend analysis was utilized to determine the linear trend analyses of the densitometry results.

\section{Results}

Effects of inducers and cytokines on glioblastoma T-98G secretion of MMP-2 and MMP-9. Glioblastoma T-98G cells expressed a band corresponding to MMP-2. Table I shows the quantitative densitometry results from the effects of PMA, TNF- $\alpha$, IL-1 $\beta$ and LPS on MMP-2 and MMP-9 expression in the T-98G cells. Upon gelatinase zymography, T-98G cells demonstrated strong expression of MMP-2 and induction of MMP-9 with PMA treatment. PMA treatment showed increased MMP-2 secretion from 0-25 ng/ml and decreased secretion at 50 and $100 \mathrm{ng} / \mathrm{ml}$ with no significant overall effect on expression of MMP-2 (linear trend $\mathrm{R}^{2}=0.153$ ). PMA showed increased MMP-9 secretion from 10 to $25 \mathrm{ng} / \mathrm{ml}$ followed by decreased secretion at 50 and 100, again with no significant overall effect on secretion of MMP-9 (linear trend $\mathrm{R}^{2}=0.281$ ). See Fig. 1 for PMA results. T-98G cells demonstrated strong expression of MMP-2 and slight induction of MMP-9 with TNF- $\alpha$ treatment. TNF- $\alpha$ treatment showed increased MMP-2 secretion from 0-1 ng/ml and decreased secretion at 10 and $25 \mathrm{ng} / \mathrm{ml}$ with no significant overall effect on expression of MMP-2 (linear trend $\mathrm{R}^{2}=0.0 .066$ ). TNF- $\alpha$ showed dose-dependent increased MMP-9 secretion (linear 
A

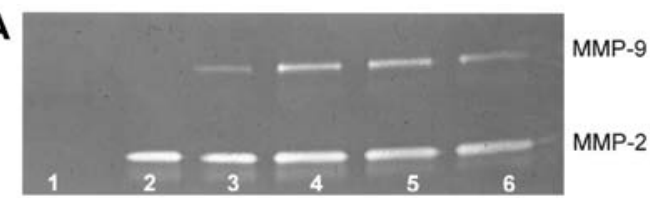

B

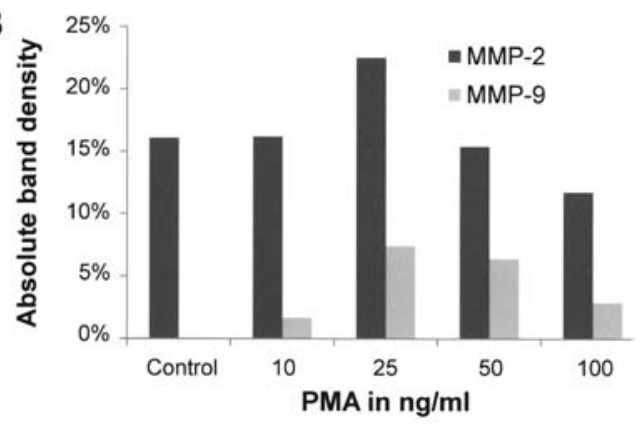

Figure 1. Effect of PMA on glioblastoma T-98G cell MMP-2 and MMP-9 secretion. (A) Gelatinase zymogram and (B) densitometry analysis of T-98G cell MMP-2 and MMP-9 secretion. Lane 1, markers; lane 2, control; lanes 3-6, PMA at 10, 25, 50 and $100 \mathrm{ng} / \mathrm{ml}$.
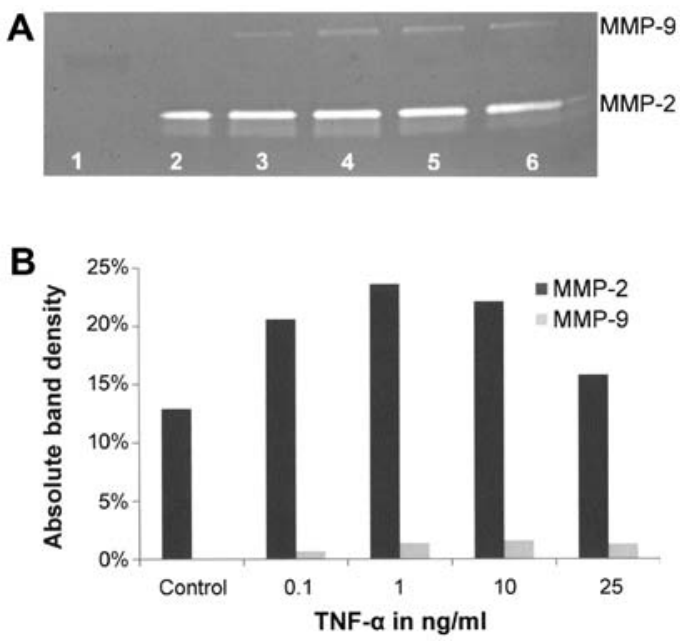

Figure 2. Effect of TNF- $\alpha$ on glioblastoma T-98G cell MMP-2 and MMP-9 secretion. (A) Gelatinase zymogram and (B) densitometry analysis of T-98G cell MMP-2 and MMP-9 secretion. Lane 1, markers; lane 2, control; lanes $3-6, \mathrm{TNF} \alpha$ at $0.1,1,10$ and $25 \mathrm{ng} / \mathrm{ml}$.
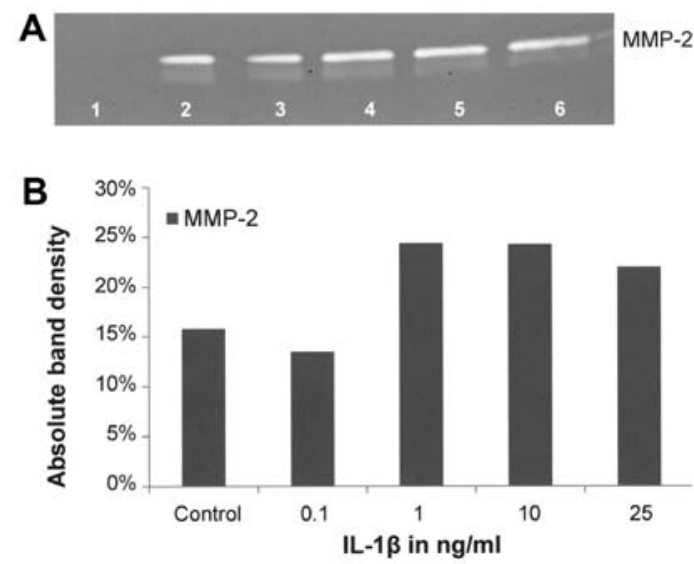

Figure 3. Effect of IL-1 $\beta$ on glioblastoma T-98G cell MMP-2 and MMP-9 secretion. (A) Gelatinase zymogram and (B) densitometry analysis of T-98G MMP-2 secretion. Lane 1, marker; lane 2, control; lanes 3-6, IL-1 $\beta$ at $0.1,1$, 10 and $25 \mathrm{ng} / \mathrm{ml}$.
Table I. Effect of inducers on glioblastoma T-98G MMP-2 and MMP-9 secretion.

\begin{tabular}{|c|c|c|}
\hline & MMP-2 (\%) & MMP-9 (\%) \\
\hline \multicolumn{3}{|c|}{ PMA (ng/ml) } \\
\hline Control & 16.1 & 0 \\
\hline 10 & 16.2 & 1.67 \\
\hline 25 & 22.5 & 7.37 \\
\hline 50 & 15.35 & 6.42 \\
\hline 100 & 11.7 & 2.85 \\
\hline \multicolumn{3}{|c|}{ TNF- $\alpha(n g / m l)$} \\
\hline Control & 12.9 & 0 \\
\hline 0.1 & 20.6 & 0.7 \\
\hline 1 & 23.6 & 1.4 \\
\hline 10 & 22.1 & 1.6 \\
\hline 25 & 15.8 & 1.3 \\
\hline \multicolumn{3}{|c|}{$\mathrm{IL}-1 \beta(\mathrm{ng} / \mathrm{ml})$} \\
\hline Control & 15.8 & 0 \\
\hline 0.1 & 13.5 & 0 \\
\hline 1 & 24.4 & 0 \\
\hline 10 & 24.3 & 0 \\
\hline \multirow[t]{2}{*}{25} & 22.0 & 0 \\
\hline & MMP-2 inactive (\%) & MMP-2 active (\%) \\
\hline \multicolumn{3}{|c|}{ LPS $(\mu \mathrm{g} / \mathrm{ml})$} \\
\hline Control & 11.7 & 0 \\
\hline 10 & 17.4 & 3.9 \\
\hline 25 & 15.1 & 9.4 \\
\hline 50 & 9.7 & 10.8 \\
\hline 100 & 5.3 & 16.7 \\
\hline
\end{tabular}

MMP, matrix metalloproteinase; PMA, phorbol 12-myristate 13-acetate; TNF- $\alpha$, tumor necrosis factor- $\alpha$; IL- $1 \beta$, interleukin- $1 \beta$.

trend $\left.\mathrm{R}^{2}=0.721\right)$. See Fig. 2 for TNF- $\alpha$ results. IL- $1 \beta$ demonstrated a slight dose-dependent increase in T-98G secretion of MMP-2 (linear trend $\mathrm{R}^{2}=0.529$ ), but no induction of MMP-9. See Fig. 3 for IL-1 $\beta$ results. LPS treatment showed dosedependent decreased inactive MMP-2 secretion (linear trend $\mathrm{R}^{2}=0.473$ ) and increased active MMP-2 secretion (linear trend $\mathrm{R}^{2}=0.977$ ) (Fig. 4).

Effects of chemical inhibitors on glioblastoma T-98G cell secretion of MMP-2 and MMP-9. Table II shows the quantitative densitometry results from the effects of chemical inhibitors doxycycline, actinomycin D, cyclohexamide and dexamethasone on MMP-2 and MMP-9 expression in the glioblastoma T-98G cell line. Doxycycline inhibited T-98G cell MMP-2 secretion in a dose-dependent manner with $73 \%$ blockage at $100 \mu \mathrm{M}$ (linear trend $\mathrm{R}^{2}=0.899$ ). Following treatment with PMA $100 \mathrm{ng} / \mathrm{ml}$, doxycycline downregulated the expression of T-98G cell MMP-2 in a dose-dependent manner, with $73 \%$ blockage at $100 \mu \mathrm{M}\left(\mathrm{R}^{2}=0.898\right)$ and total blockage of MMP-9 at $10 \mu \mathrm{M}$ (linear trend $\mathrm{R}^{2}=0.500$ ). See 
A
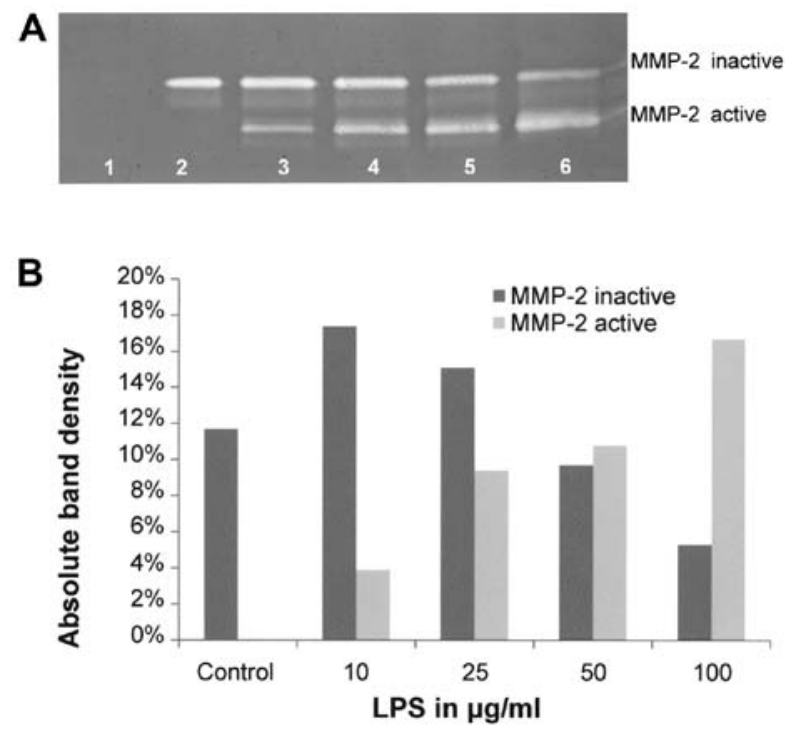

Figure 4. Effect of LPS on glioblastoma T-98G cell MMP-2 and MMP-9 secretions. (A) Gelatinase zymogram and (B) densitometry analysis of T-98G MMP-2 secretion. Lane 1, markers. Lane 2, control. Lanes 3-6, IL-1 $\beta$ at 0.1, 1,10 and $25 \mathrm{ng} / \mathrm{ml}$.

Fig. 5 for doxycycline effects on untreated and PMA-treated T-98G cells. Actinomycin D had moderate inhibitory effect on MMP-2 secretion $\left(\mathrm{R}^{2}=0.725\right)$ with $\sim 25 \%$ inhibition at 2 and $4 \mu \mathrm{M}$, as shown in Fig. 6. Cyclohexamide had a potent dose-dependent inhibitory effect on MMP-2 secretion by $\mathrm{T}-98 \mathrm{G}$ cells with $93 \%$ inhibition at $4 \mu \mathrm{M}$ (linear trend $\mathrm{R}^{2}=0.787$ ), as shown in Fig. 7. Dexamethasone had a moderate inhibitory effect on MMP-2, with inhibition of $23 \%$ at $50 \mu \mathrm{M}$ compared to the control (Fig. 8).

Effects of natural inhibitors on glioblastoma T-98G secretion of MMP-2 and MMP-9. Table II shows the quantitative densitometry results from the effects of natural inhibitors EGCG, the NM and retinoic acid on MMP-2 and MMP-9 expression in glioblastoma T-98G cells. EGCG potently downregulated T-98G expression of MMP-2 in a dose-dependent manner, with total blockage at $50 \mu \mathrm{M}$ (linear trend $\mathrm{R}^{2}=0.712$ ), as shown in Fig. 9A and C. EGCG showed dose-dependent inhibition of PMA (100 ng/ml)-induced MMP-9 secretion (linear trend $\mathrm{R}^{2}=0.866$ ) and of MMP-2 (linear trend $\mathrm{R}^{2}=0.877$ ) with total blockage of both at $50 \mu \mathrm{M}$, as shown in Fig. 9B and D. NM inhibited secretion of MMP-2 by uninduced T-98G cells in a dose-dependent manner (linear trend $\mathrm{R}^{2}=0.8706$ ) with virtual total block at $1,000 \mu \mathrm{g} / \mathrm{ml}$ (Fig. 10A and C). NM showed dose-dependent inhibition of MMP-2 and MMP-9 expression in PMA-treated T-98G cells with total blockage of MMP-2 at $1,000 \mu \mathrm{g} / \mathrm{ml}$ and MMP-9 at $100 \mu \mathrm{g} / \mathrm{ml}$ (linear trends $\mathrm{R}^{2}=0.863$ and 0.742 , respectively), as shown in Fig. 10B and D. Retinoic acid inhibited T-98G MMP-2 secretion by $54 \%$ at $50 \mu \mathrm{M}$ (Fig. 8).

\section{Discussion}

Elevated MMP levels correlate with glioblastoma tumor progression, as documented in clinical studies (6-8). Thus, knowledge of MMP regulation is of importance for developing
Table II. Effect of inhibitors on glioblastoma T-98G MMP-2 and MMP-9 secretion.

$\frac{\text { Untreated }}{\text { MMP-2 (\%) }} \frac{\text { PMA } 100 \text { ng/ml-treated }}{\text { MMP-2 (\%) MMP-9 (\%) }}$

\begin{tabular}{lccc}
\hline $\begin{array}{l}\text { Doxycycline }(\mu \mathrm{M}) \\
\text { Control }\end{array}$ & 36.9 & 33.0 & 10.6 \\
10 & 22.2 & 19.8 & 0 \\
25 & 19.1 & 17.1 & 0 \\
50 & 11.8 & 10.5 & 0 \\
100 & 10.0 & 8.9 & 0 \\
EGCG $(\mu \mathrm{M})$ & & & \\
Control & 40.0 & 44.9 & 9.2 \\
10 & 53.5 & 29.3 & 7.0 \\
25 & 6.5 & 8.3 & 1.2 \\
50 & 0.5 & 0 & 0 \\
100 & 0 & 0 & 0 \\
$\mathrm{NM}(\mu \mathrm{g} / \mathrm{ml})$ & & & \\
Control & 36.9 & 31.4 & 1.9 \\
10 & 32.8 & 37.1 & 1.2 \\
50 & 19.3 & 22.0 & 0.1 \\
100 & 8.2 & 5.0 & 0 \\
500 & 2.2 & 1.3 & 0 \\
1,000 & 0.6 & 0 & 0
\end{tabular}

Actinomycin D $(\mu \mathrm{g} / \mathrm{ml})$

$\begin{array}{lrl}\text { Control } & 100.0 & 0 \\ 2 & 75.3 & 0 \\ 4 & 76.1 & 0 \\ \text { Cyclohexamide }(\mu \mathrm{g} / \mathrm{ml}) & & \\ \text { Control } & 100.0 & 0 \\ 2 & 11.1 & 0 \\ 4 & 6.5 & 0\end{array}$

Dexamethasone $(\mu \mathrm{M})$

$\begin{array}{lrl}\text { Control } & 100.0 & 0 \\ 50 & 77.4 & 0\end{array}$

Retinoic acid $(\mu \mathrm{M})$

$\begin{array}{lrr}\text { Control } & 100.0 & 0 \\ 50 & 45.7 & 0\end{array}$

MMP, matrix metalloproteinase; PMA, phorbol 12-myristate 13-acetate; EGCG, epigallocatechin gallate; NM, nutrient mixture.

therapeutic strategies for glioblastoma. Extracellular factors, such as the inflammatory cytokines IL- $1 \beta$ and TNF- $\alpha$ have been implicated in inflammation-driven tumor growth and progression of glioblastoma $(12,13)$. Esteve et al reported that production of MMP-9 in glioma cells is tightly regulated by IL-1, TNF $\alpha$ and TGF $\beta_{2}(18)$.

In the present study, we compared MMP secretion patterns by inducers, cytokines and mitogens, such as PMA, TNF $\alpha$, IL-1 $\beta$ and LPS in glioblastoma T-98G cells. Surprisingly, we found that MMP-9 was not significantly 
A

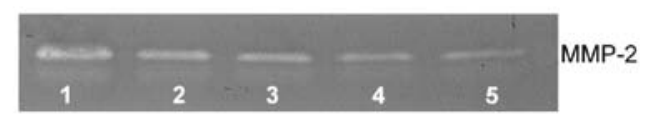

C

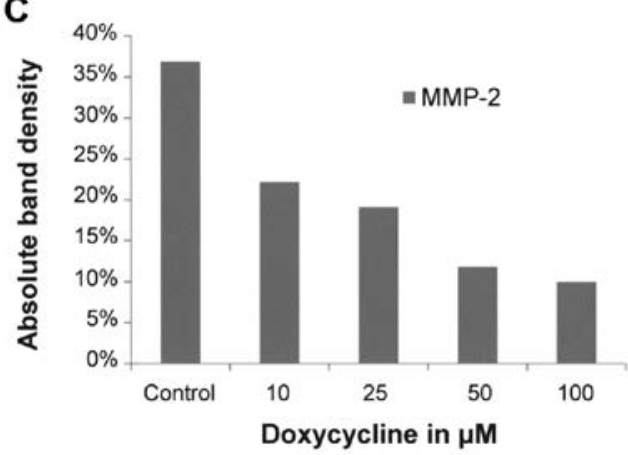

B

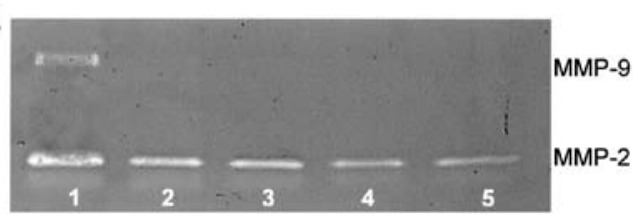

D $35 \%$

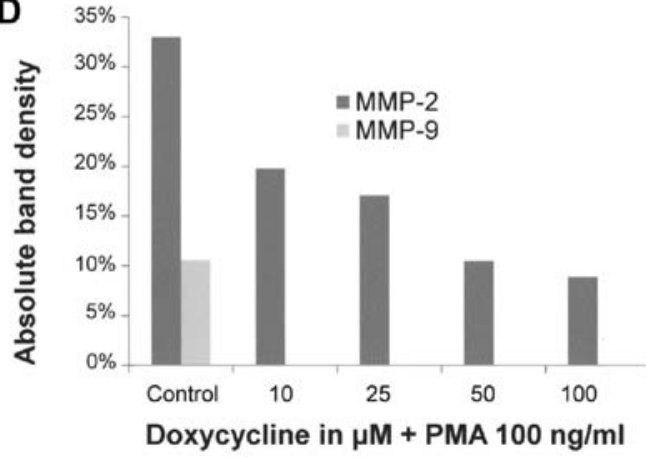

Figure 5. Effect of doxycycline on secretion of MMP-2 and MMP-9 by normal and PMA $100 \mathrm{ng} / \mathrm{ml}$-treated glioblastoma T-98G cells. Gelatinase zymograms of (A) normal T-98GF cell and (B) PMA-treated T-98G cell MMP-2 and MMP-9 secretion. Densitometry analyses of (C) normal T-98G cell and (D) PMA-treated T-98G cell MMP-2 and MMP-9 secretion. Lane 1, control; lanes 2-5, doxycycline at 10, 25, 50 and $100 \mu \mathrm{M}$.
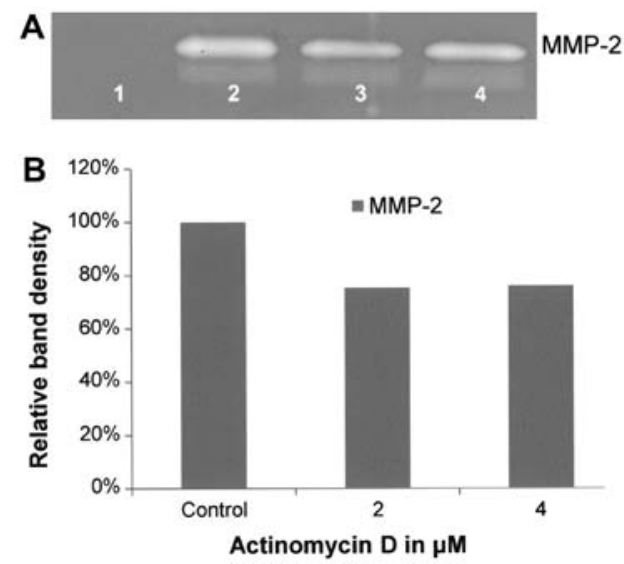

Figure 6. Effect of actinomycin D on glioblastoma T-98G cell MMP-2 secretion. (A) Gelatinase zymogram and (B) densitometry analysis of T-98G cell MMP-2 secretion. Lane 1, marker; lane 2, control; lanes 3-4, actinomycin D at 2 and $4 \mu \mathrm{M}$.
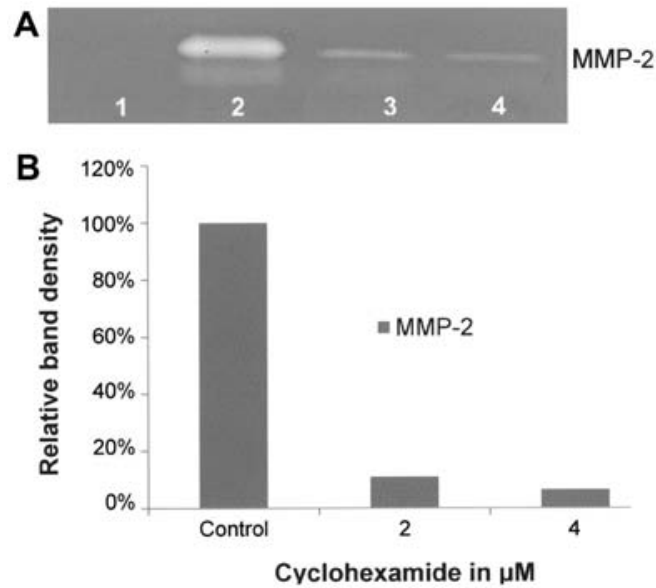

Figure 7. Effect of cyclohexamide on glioblastoma T-98G cell MMP-2 secretion. (A) Gelatinase zymogram and (B) densitometry analysis of T-98G cell MMP-2 secretion. Lane 1, marker; lane 2, control; lanes 3-4, cyclohexamide at 2 and $4 \mu \mathrm{M}$.
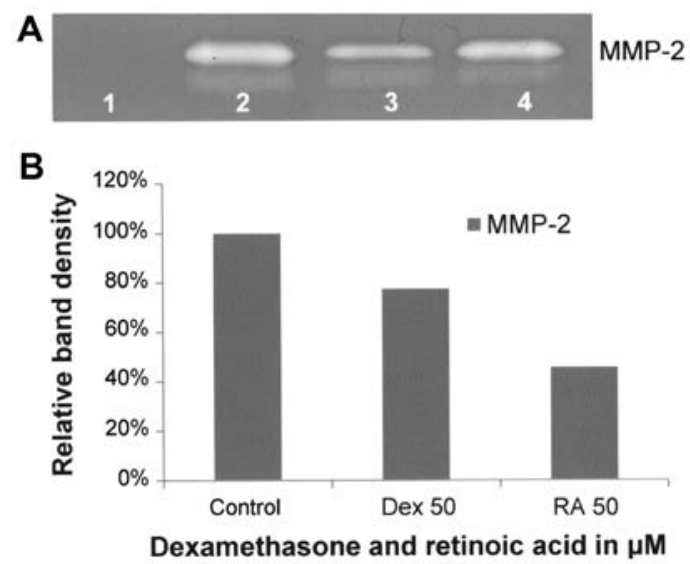

Figure 8. Effect of dexamethasone and retinoic acid on glioblastoma T-98G cell MMP-2 secretion. (A) Gelatinase zymogram and (B) densitometry analysis of T-98G MMP-2 secretion. Lane 1, marker; lane 2, control; lane 3, dexamethasone at $50 \mu \mathrm{M}$; lane 4 , retinoic acid at $50 \mu \mathrm{M}$.

enhanced by PMA, TNF $\alpha$ and IL-1 $\beta$ in the present study. LPS increased active MMP-2 secretion and decreased inactive MMP-2 secretion, but had no effect on MMP-9. In addition, we investigated the effect of inhibitors, such as doxycycline, EGCG, NM, dexamethasone, cyclohexamide, retinoic acid and agents that affect transcription and translation levels, such as actinomycin D. All inhibitors tested downregulated MMP secretion by T-98G cells. Doxycycline, a chemical inhibitor, potently downregulated T-98G secretion of MMP-2 and PMA-induced MMP-9. Cyclohexamide demonstrated potent inhibitory action on T-98G MMP-2 secretion, while actinomycin D and dexamethasone had moderate inhibitory effects on MMP-2. Among the natural inhibitors, NM and its component EGCG potently downregulated T-98G cell secretion of MMP-2 and MMP-9. Retinoic acid strongly inhibited MMP-2 secretion.

In addition to individual compounds, we tested the effects of a specific nutrient mixture, NM, which has demonstrated 
A
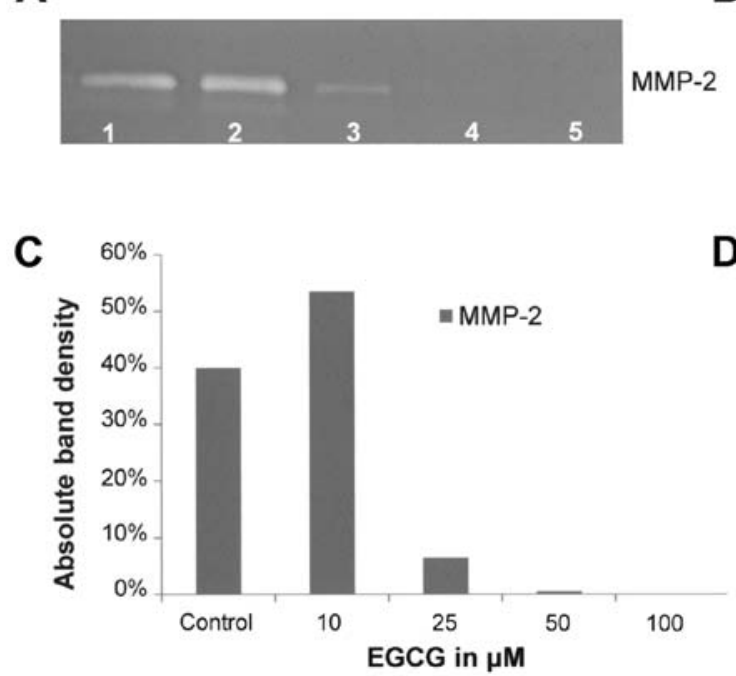

B

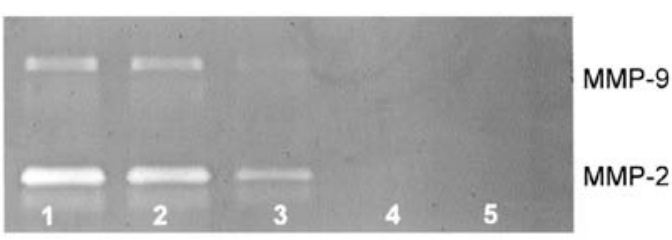

D

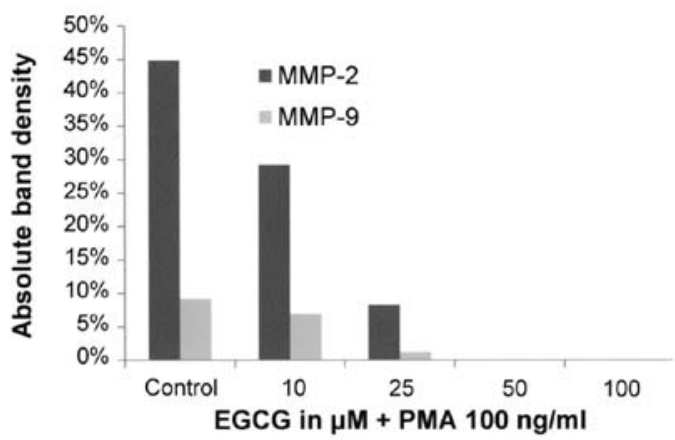

Figure 9. Effect of EGCG on MMP-2 and MMP-9 secretion by normal and PMA $100 \mathrm{ng} / \mathrm{ml}$-treated glioblastoma T-98G cells. Gelatinase zymograms of (A) normal T-98G cell and (B) PMA-treated T-98G cell MMP-2 and MMP-9 secretion. Densitometry analyses of (C) normal T-98G cell and (D) PMA-treated T-98G cell MMP-2 and MMP-9 secretion. Lane 1, control; lanes 2-5, EGCG at 10, 25, 50 and $100 \mu \mathrm{M}$.

A

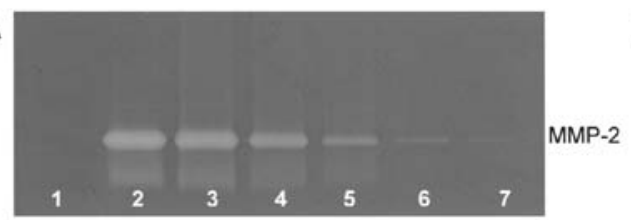

C

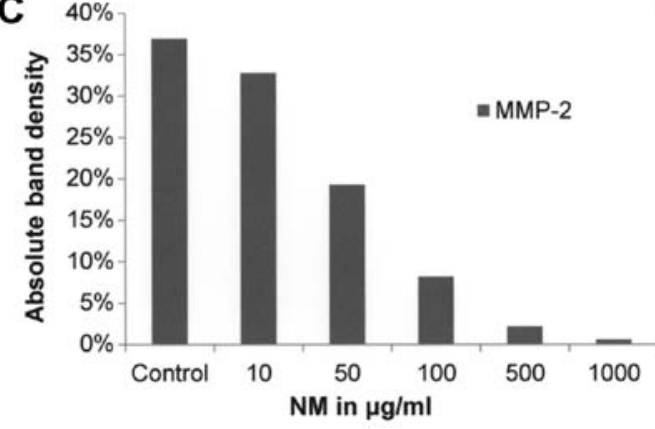

B

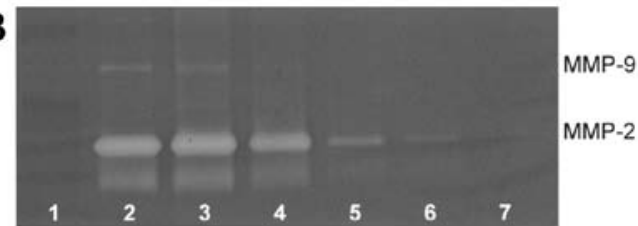

D

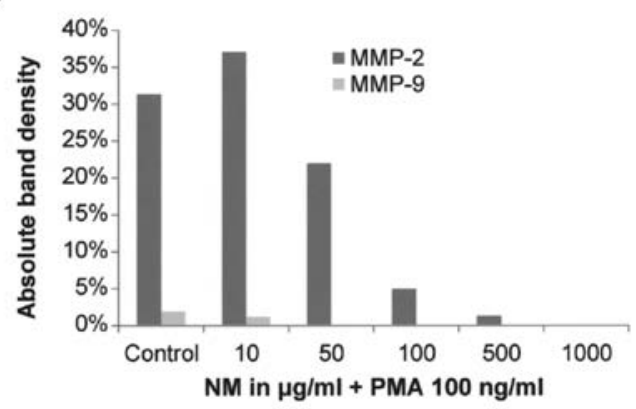

Figure 10. Effect of NM on MMP-2 and MMP-9 secretion by normal and PMA $100 \mathrm{ng} / \mathrm{ml}$-treated glioblastoma T-98G cells. Gelatinase zymograms of (A) normal T-98G cell and (B) PMA-treated T-98G cell MMP-2 and MMP-9 secretion. Densitometry analyses of (C) normal T-98G cell and (D) PMA-treated T-98G cell MMP-2 and MMP-9 secretion. Lane1, markers; lane 2, control; lanes 3-7, NM at 10, 50, 100, 500 and 1,000 $\mu \mathrm{g} / \mathrm{ml}$.

anticancer efficacy in various in vitro and in vivo studies by affecting various mechanisms, including secretion of MMPs (19). Optimal ECM structure is dependent upon sufficient ascorbic acid, lysine and proline to support proper collagen synthesis and hydroxylation of collagen fibers. Lysine also contributes to ECM stability as a natural inhibitor of plasmin-induced proteolysis $(20,21)$. Copper and manganese act as co-factors for hydroxylase enzymes and galactosyl and glucosyl transferases, respectively, to form collagen $(22,23)$. Green tea extract has been shown to be potent in modulating cancer cell growth, apoptosis, metastasis and angiogenesis (23-29), and daily consumption has demonstrated delayed cancer onset of breast cancer, as well as a lower recurrence rate and longer remission (30). $N$-acetyl cysteine and selenium have been documented to inhibit tumor cell MMP-9 and invasive activities and migration of endothelial cells through the ECM (31-33). Ascorbic acid has been documented to modulate cancer cell and tumor growth as well as to prevent metastasis (34-39) and low levels of ascorbic acid are found in cancer patients $(40,41)$. Low levels of arginine limit NO production, an inducer of apoptosis (42).

In conclusion, our results showed that inducers, cytokines and mitogens showed variable effects on T-98G cell secretion of MMP-2 and MMP-9. However, all inhibitors tested downregulated glioblastoma T-98G cell MMP-2 and MMP-9 secretion, suggesting the clinical use of MMP inhibitors, particularly potent and non-toxic ones as the nutrient mixture and its component EGCG in the management of glioblastomas. 


\section{Acknowledgements}

The present study was funded by Dr. Rath Health Foundation (Santa Clara, CA, USA), a non-profit organization.

\section{References}

1. ACS: What are the key statistics about brain and spinal cordtumors? Last revised 1/21/2016. Accessed 9/15/16. http://www.cancer.org/ cancer/braincnstumorsinadults/detailedguide/brain-and-spinalcord-tumors-in-adults-key-statistics.

2. ABTA (American Brain Tumor Association): Brain Tumor Facts Last revised 12/2015. Accessed 9/15/16. http://www.abta.org/ about-us/news/brain-tumor-statistics.

3. Yurchenco PD and Schittny JC: Molecular architecture of basement membranes. FASEB J 4: 1577-1590, 1990.

4. Barsky SH, Siegal GP, Jannotta F and Liotta LA: Loss of basement membrane components by invasive tumors but not by their benign counterparts. Lab Invest 49: 140-147, 1983.

5. Liotta LA, Tryggvason K, Garbisa S, Hart I, Foltz CM and Shafie S: Metastatic potential correlates with enzymatic degradation of basement membrane collagen. Nature 284: 67-68, 1980.

6. Forsyth PA, Laing TD, Gibson AW, Rewcastle NB, Brasher P, Sutherland G, Johnston RN and Edwards DR: High levels of gelatinase-B and active gelatinase-A in metastatic glioblastoma. J Neurooncol 36: 21-29, 1998.

7. Jäälinojä J, Herva R, Korpela M, Höyhtyä M and TurpeenniemiHujanen T: Matrix metalloproteinase 2(MMP-2) immunoreactive protein is associated with poor grade and survival in brain neoplasms. J Neurooncol 46: 81-90, 2000.

8. Smith ER, Zurakowski D, Saad A, Scott RM and Moses MA: Urinary biomarkers predict brain tumor presence and response to therapy. Clin Cancer Res 14: 2378-2386, 2008.

9. de Visser KE and Coussens LM: The inflammatory tumor microenvironment and its impact on cancer development. Contrib Microbiol 13: 118-137, 2006.

10. Coussens LM and Werb Z: Inflammation and cancer. Nature 420 : 860-867, 2002

11. Mantovani A, Allavena P, Sica A and Balkwill F: Cancer-related inflammation. Nature 454: 436-444, 2008.

12. Germano G, Allavena P and Mantovani A: Cytokines as a key component of cancer-related inflammation. Cytokine 43 : 374-379, 2008

13. Allavena P, Garlanda C, Borrello MG, Sica A and Mantovani A Pathways connecting inflammation and cancer. Curr Opin Genet Dev 18: 3-10, 2008.

14. Gridley DS, Loredo LN, Slater JD, Archambeau JO, Bedros AA, Andres ML and Slater JM: Pilot evaluation of cytokine levels in patients undergoing radiotherapy for brain tumor. Cancer Detect Prev 22: 20-29, 1998.

15. Zhou W, Jiang Z, Li X, Xu Y and Shao Z: Cytokines: Shifting the balance between glioma cells and tumor microenvironment after irradiation. J Cancer Res Clin Oncol 141: 575-589, 2015.

16. Ilyin SE, González-Gómez I, Romanovicht A, Gayle D, Gilles FH and Plata-Salamán CR: Autoregulation of the interleukin-1 system and cytokine-cytokine interactions in primary human astrocytoma cells. Brain Res Bull 51: 29-34, 2000.

17. Ryuto M, Ono M, Izumi H, Yoshida S, Weich HA, Kohno K and Kuwano M: Induction of vascular endothelial growth factor by tumor necrosis factor alpha in human glioma cells. Possible roles of SP-1. J Biol Chem 271: 28220-28228, 1996.

18. Esteve PO, Tremblay P, Houde M, St-Pierre Y and Mandeville R In vitro expression of MMP-2 and MMP-9 in glioma cells following exposure to inflammatory mediators. Biochim Biophys Acta 1403: 85-96, 1998 .

19. Niedzwiecki A, Roomi MW, Kalinovsky T and Rath M: Micronutrient synergy - a new tool in effective control of metastasis and other key mechanisms of cancer. Cancer Metastasis Rev 29: 529-542, 2010.

20. Rath M and Pauling L: Plasmin-induced proteolysis and the role of apoprotein(a), lysine and synthetic analogs. Orthomolecular Med 7: 17-23, 1992.

21. Sun Z, Chen YH, Wang P, Zhang J, Gurewich V, Zhang P and Liu JN: The blockage of the high-affinity lysine binding sites of plasminogen by EACA significantly inhibits prourokinase-induced plasminogen activation. Biochim Biophys Acta 1596: 182-192, 2002.
22. Mussini E, Hutton JJ Jr and Udenfriend S: Collagen proline hydroxylase in wound healing, granuloma formation, scurvy, and growth. Science 157: 927-929, 1967.

23. Kivirikko KI and Myllylä R: Collagen glycosyltransferases. Int Rev Connect Tissue Res 8: 23-72, 1979.

24. Valcic S, Timmermann BN, Alberts DS, Wächter GA, Krutzsch M, Wymer J and Guillén JM: Inhibitory effect of six green tea catechins and caffeine on the growth of four selected human tumor cell lines. Anticancer Drugs 7: 461-468, 1996.

25. Mukhtar H and Ahmad N: Tea polyphenols: Prevention of cancer and optimizing health. Am J Clin Nutr 71 (Suppl 6): S1698S-S1704S, 2000

26. Yang GY, Liao J, Kim K, Yurkow EJ and Yang CS: Inhibition of growth and induction of apoptosis in human cancer cell lines by tea polyphenols. Carcinogenesis 19: 611-616, 1998.

27. Taniguchi S, Fujiki H, Kobayashi H, Go H, Miyado K, Sadano H and Shimokawa R: Effect of (-)-epigallocatechin gallate, the main constituent of green tea, on lung metastasis with mouse B16 melanoma cell lines. Cancer Lett 65: 51-54, 1992.

28. Hara Y: Green Tea:HealthBenefitsandApplications.MarcelDekker, New York, Basel, 2001. http://dx.doi.org/10.1201/9780203907993.

29. Gupta S, Hastak K, Afaq F, Ahmad N and Mukhtar H: Essential role of caspases in epigallocatechin-3-gallate-mediated inhibition of nuclear factor kappa B and induction of apoptosis. Oncogene 23: 2507-2522, 2004.

30. Fujiki H, Suganuma M, Okabe S, Sueoka E, Suga K, Imai K, Nakachi K and Kimura S: Mechanistic findings of green tea as cancer preventive for humans. Proc Soc Exp Biol Med 220: 225-228, 1999.

31. Kawakami S, Kageyama Y, Fujii Y, Kihara K and Oshima H: Inhibitory effect of $N$-acetylcysteine on invasion and MMP-9 production of T24 human bladder cancer cells. Anticancer Res 21: 213-219, 2001.

32. Morini M, Cai T, Aluigi mg, Noonan DM, Masiello L, De Flora S, D'Agostini F, Albini A and Fassina G: The role of the thiol $N$-acetylcysteine in the prevention of tumor invasion and angiogenesis. Int J Biol Markers 14: 268-271, 1999.

33. Yoon SO, Kim MM and Chung AS: Inhibitory effect of selenite on invasion of HT1080 tumor cells. J Biol Chem 276: 20085-20092, 2001.

34. Cha J, Roomi MW, Ivanov V, Kalinovsky T, Niedzwiecki A and Rath M: Ascorbate supplementation inhibits growth and metastasis of B16FO melanoma and 4T1 breast cancer cells in vitamin C-deficient mice. Int J Oncol 42: 55-64, 2013.

35. Naidu KA, Karl RC, Naidu KA and Coppola D: Antiproliferative and proapoptotic effect of ascorbyl stearate in human pancreatic cancer cells: Association with decreased expression of insulin-like growth factor 1 receptor. Dig Dis Sci 48: 230-237, 2003.

36. Anthony HM and Schorah CJ: Severe hypovitaminosis C in lung-cancer patients: The utilization of vitamin $\mathrm{C}$ in surgical repair and lymphocyte-related host resistance. Br J Cancer 46: 354-367, 1982.

37. Maramag C, Menon M, Balaji KC, Reddy PG and Laxmanan S: Effect of vitamin $C$ on prostate cancer cells in vitro: Effect on cell number, viability, and DNA synthesis. Prostate 32: 188-195, 1997.

38. Koh WS, Lee SJ, Lee H, Park C, Park MH, Kim WS, Yoon SS, Park K, Hong SI, Chung MH, et al: Differential effects and transport kinetics of ascorbate derivatives in leukemic cell lines. Anticancer Res 18: 2487-2493, 1998

39. Chen Q, Espey mg, Krishna MC, Mitchell JB, Corpe CP, Buettner GR, Shacter E and Levine M: Pharmacologic ascorbic acid concentrations selectively kill cancer cells: Action as a pro-drug to deliver hydrogen peroxide to tissues. Proc Natl Acad Sci USA 102: 13604-13609, 2005

40. Núñez Martín C, Ortiz de Apodaca y Ruiz A and Ruiz A: Ascorbic acid in the plasma and blood cells of women with breast cancer. The effect of the consumption of food with an elevated content of this vitamin. Nutr Hosp 10: 368-372, 1995 (In Spanish).

41. Kurbacher CM, Wagner U, Kolster B, Andreotti PE, Krebs D and Bruckner HW: Ascorbic acid (vitamin C) improves the antineoplastic activity of doxorubicin, cisplatin, and paclitaxel in human breast carcinoma cells in vitro. Cancer Lett 103: 183-189, 1996.

42. Cooke JP and Dzau VJ: Nitric oxide synthase: Role in the genesis of vascular disease. Annu Rev Med 48: 489-509, 1997. 